\title{
KATALOG RZECZOWY A POTRZEBY KOMPUTERYZACJI BIBLIOTEKI
}

Nie sposób przecenić roli katalogu rzeczowego, zwłaszcza w dużej bibliotece. Korzystają z niego czytelnicy nie dysponujący pełnym opisem formalnym dokumentów, którzy chcą dowiedzieć się jakie pozycje z interesującej ich dziedziny wiedzy, posiada biblioteka. Analogiczną pomocą służą indeksy przedmiotowe katalogów zautomatyzowanych.

Zasygnalizowany $w$ tytule problem omówimy na podstawie doświadczeń Biblioteki Uniwersyteckiej Katolickiego Uniwersytetu Lubelskiego (BU KUL).

W BU KUL prowadzony jest jeden rodzaj katalogu rzeczowego, katalog systematyczny. Dzieli on, zgodnie ze swym charakterem, piśmiennictwo na hierarchicznie ułożone działy i poddziały. Pełny opis struktury naszego katalogu przedstawił B. Królikowski na Konferencji w Jarocinie ${ }^{1}$. Tu zostaną wyakcentowane tylko pewne, wybrane cechy charakterystyczne.

Katalog systematyczny BU KUL prowadzony jest od ponad 40 lat, od 1952 r. Obejmuje całość piśmiennictwa, tzw. druków zwartych nowych, gromadzonych w Bibliotece. Nie mamy katalogu rzeczowego wydawnictw ciągłych. Dla starych druków opracowany jest katalog działowy.

Przy klasyfikacji posługujemy się schematami. One, choć na etapie tworzenia katalogu, zapożyczone z Biblioteki Jagiellońskiej, wielokrotnie przebudowywane, rozszerzane i zmieniane, są własnością BU KUL. W latach 60-tych zespół pod kierunkiem prof. S. Kamińskiego wyodrębnił metanaukowe poddziały wspólne.

Za jednostkę klasyfikacji przyjmujemy jednostkę opisu formalnego. Dla dzieł wielotomowych, o wspólnym haśle formalnym, szukamy przydziału ogólnego, obejmującego całość tematyczną dokumentu. Do prac wielodziałowych, z pogranicza nauk, stosujemy przydziały wielokrotne.

${ }^{1}$ B. K róli k ow s k i, Katalog systematyczny Biblioteki Uniwersyteckiej Katolickiego Uniwersytetu Lubelskiego, w: Opracowanie rzeczowe w dużych bibliotekach uniwersyteckich. Materiaty $z$ Konferencji 22-24 maja 1986 roku Jarocin, Warszawa 1989, s. 123-128. 
Katalog zawiera w sobie system odsyłaczy rzeczowych całkowitych i uzupełniających.

Przy klasyfikacji uwzględniane są kryteria metodologiczne. Katalog systematyczny jest katalogiem aspektowym. Przede wszystkim sposób prowadzenia badań, użyty przez autora książki, decyduje o zaliczeniu pozycji do danego działu. Czasem, zwłaszcza na najniższych stopniach podziału, kryterium to jest łamane i klasyfikacja przypomina przydział przedmiotowy.

Wybór tego typu katalogu rzeczowego, ułatwia opracowywanie piśmiennictwa ze zróżnicowanym stopniem szczegółowości. Potrzebę taką wyznacza specyfika zbiorów BU KUL. Najobficiej jest w nich reprezentowana teologia i religioznawstwo. Dla ilustracji podamy, że dział G. - RELIGIOZNAWSTWO I TEOLOGIA zajmuje w naszym katalogu 266 szufladek, a dział P. NAUKI MATEMATYCZNO-PRZYRODNICZE tylko 11 szufladek.

Przytoczymy jeszcze kilka cech różniących katalog BU KUL od porównywalnych katalogów tego rodzaju innych bibliotek.

Katalog systematyczny BU KUL rejestruje całość gromadzonego piśmiennictwa, łącznie $\mathrm{z}$ tekstami literackimi.

Dział J. - HISTORIA obejmuje: nauki pomocnicze historii, historię polityczną, aż po czasy najnowsze, wprost bieżące oraz historię kultury i wojskowości. Historia gospodarcza i historia społeczna włączone są do działu $\mathrm{O}$. NAUKI SPOEECZNO-EKONOMICZNE. W tym samym dziale, w ramach filozofii społecznej, wyodrębniona jest katolicka nauka społeczna.

Przez nauki polityczne rozumiemy teorię polityki. Natomiast dokumenty o działaniach politycznych poszczególnych rządów i państw zaliczamy do historii politycznej.

Karty w katalogu porządkuje układ chronologiczny lat wydania dokumentów.

Indeks przedmiotowy katalogu systematycznego istnieje tylko w wersji roboczej. Opóźnienie w jego wykończeniu i udostępnieniu czytelnikom spowodowane jest ograniczoną ilością etatów.

Książki klasyfikowane są z autopsji przez referentów poszczególnych działów. Są to osoby posiadające wykształcenie specjalistyczne, co ułatwia orientację $\mathrm{w}$ piśmiennictwie $\mathrm{z}$ danej dziedziny wiedzy. Ze względów kadrowych, są to referenci tylko głównych działów piśmiennictwa gromadzonego przez BU KUL.

Nigdy nie została sformułowana na piśmie metodyka klasyfikacji. Doświadczenia są przekazywane pracownikom ustnie przez starszych kolegów. Jedyną pomocą, oprócz roboczej wersji indeksu, są schematy katalogu.

Do tej pory, w BU KUL klasyfikacja rzeczowa wyprzedza opis formalny, alfabetyczny.

Rozwój bibliotekarstwa poszedł w stronę automatyzacji. Ma ona wykluczyć wielokrotne opracowywanie tego samego dokumentu przez kilka biblio- 
tek. Czytelnikowi natomiast ma umożliwiać przeglądanie katalogów wielu bibliotek $\mathrm{z}$ jednego stanowiska.

Konieczność komputeryzacji Biblioteki postawiła przed naszym zespołem nowe problemy i zadania.

W 1994 r. podjęto decyzję o przystąpieniu BU KUL do zespołu bibliotek posługujących się programem VTLS. Program ten, jak i przyjęty format USMARC nie wykorzystują języka klasyfikacji systematycznej. Zaistniała potrzeba opracowania języka haseł przedmiotowych, zgodnie $z$ analogicznym, używanym przez pozostałe biblioteki Zespołu.

Rezultatem poszukiwań języka informacyjno-wyszukiwawczego, prowadzonych przez zespół bibliotek polskich użytkujących VTLS, jest język haseł przedmiotowych KABA (Katalogi Automatyczne Bibliotek Akademickich). Opiera się on na języku RAMEAU, opracowywanym i wykorzystywanym przez Bibliotekę Narodową w Paryżu i biblioteki z nią współpracujące, i LCSH - języku haseł przedmiotowych Biblioteki Kongresu w Waszyngtonie ${ }^{2}$.

Jhp - KABA został przyjęty, jako wspólny i obowiązujący przez wszystkie biblioteki polskie pracujące przy pomocy VTLS.

Jednostkami leksykalnymi KABA są wyrażenia naturalnego języka polskiego. Tylko w wypadku braku odpowiednika polskiego, dopuszcza się użycie terminu obcego.

Gramatyka, natomiast, jest zgodna z gramatyką RAMEAU i LCSH${ }^{3}$. Metodyka budowy tych języków jest taka sama. Współpracujące ze sobą biblioteki polskie, opracowują hasła przedmiotowe spójne systemowo i zgodne, co do zasad posługiwania się hasłami, z wymienionymi wcześniej językami.

$W$ trzech paralelnych jiw: LCSH, RAMEAU i KABA, odpowiadające sobie terminy przyjmują analogiczne znaczenie, stosowane są w takim samym zakresie. Wchodzą w podobne relacje $z$ innymi terminami. Mają wyznaczone takie same cechy łączliwości. Termin będący tematem w RAMEAU i LCSH będzie występował w tej samej funkcji w KABA. To samo dotyczy określników i związków między terminami. Języki te są zbiorami leksykalnymi wzajemnie na sobie odwzorowanymi, poprzez relacje syntaktyczno-semantyczne.

W jhp KABA występuja 2 typy pozycji: pozycja główna i odsyłacze (5 rodzajów). Jednostki leksykalne dzielą się na 2 kategorie: tematy i określniki. Ze względu na formę reprezentacji wśród jednostek leksykalnych wyróżniamy nazwy ogólne i nazwy jednostkowe. Biorąc pod uwagę stosunek wyrażenia do zbioru cech charakteryzujących dokument, można wyodrębnić tematy i określniki rzeczowe oraz tematy i określniki formy. Cecha łączności dzieli

${ }^{2}$ Kartoteka wzorcowa jezyka KABA, cz. 1, Nazwy własne, praca zbior. pod red. J. Woźniak, Warszawa 1994.

${ }^{3}$ J. Woźni a k, System leksykalny jezzyka KABA, „Przegląd Biblioteczny”, 62 (1994) z. 3/4, s. $225-230$. 
określniki na swobodne - nieograniczonego stosowania i związane - ograniczonego stosowania. Określnik związany może występować w haśle przedmiotowym tylko $\mathrm{z}$ tematem, lub tematami, przy którym został wymieniony w kartotece wzorcowej. Określniki swobodne i związane dzielimy na: rzeczowe, geograficzne, chronologiczne, formy. Występują one po tematach w takiej właśnie kolejności.

KABA jest językiem kontrolowanym kartoteką wzorcową. Każdy termin użyty w haśle przedmiotowym musi być wcześniej wprowadzony do kartoteki wzorcowej. Ponieważ termin może wystąpić w 3 funkcjach: tematu, określnika, oraz tematu i określnika równocześnie, w khw określamy jego funkcję.

Pozycja w kartotece wzorcowej budowana jest według ścisłych zasad i obejmuje kolejno następujące po sobie strefy ${ }^{4}$.

Pierwsza $\mathrm{z}$ nich podaje hasło podstawowe. Tematem może być nazwa pospolita, nazwa osobowa, nazwa ciała zbiorowego, nazwa geograficzna, tytuł dzieła anonimowego, wydawnictwa ciągłego, anonimu klasycznego. Tu też ujawniamy cechę lączliwości z określnikami.

Druga strefa pozycji zawiera zwięzłe wyjaśnienie pojęcia, definicję terminu, gdy nie był oczywisty. Prócz tego np. w wypadku nazw osobowych podajemy dane biograficzne.

W kolejnej strefie umieszczamy informacje o związkach i relacjach danego terminu $\mathrm{z}$ innymi. Ujawniamy relacje ekwiwalencji. Wymieniamy terminy odrzucone (synonimiczne, bliskoznaczne, archaiczne, itd.). Tu umieszczamy też odpowiedniki, hasła w języku francuskim i angielskim. Podane są również torminy skojarzeniowe, terminy nadrzędne i podrzędne.

Następna strefa zawiera odsyłacze. W kolejnej znajdujemy informacje o źródłach wykorzystanych przy budowie hasła. W końcowej umieszczane jest siglum biblioteki opracowującej hasło. Osoba wprowadzająca termin do khw musi uwzględnić wszystkie strefy pozycji.

Kartoteka wzorcowa ujawnia strukturę KABA, wzajemne powiązania syntaktyczno-semantyczne pomiędzy terminami. Każde wyrażenie ma zapisaną funkcję, w której może występować. Określane jest też jego znaczenie i zakres stosowania.

Konieczność ciągłego redagowania nowych haseł do kartoteki wzorcowej, zwłaszcza w początkowym okresie prac nad językiem, jest uciążliwa. Ale jednocześnie jest niezbędnym warunkiem poprawności budowy i wykorzystywania haseł. Nie ma innego sposobu zabezpieczenia przed użyciem tego samego terminu w różnych funkcjach i znaczeniach. Gdy kartoteka wzorcowa zostanie nasycona terminami, coraz większa ilość haseł będzie się powtarzać. Wysiłek włożony w budowę khw zaprocentuje.

${ }^{4}$ A. Stanis, Stan prac nad kartotekg wzorcowa jezyka haset przedmiotowych KABA, „Przegląd Biblioteczny", 62 (1994) z. 3/4, s. 231-236. 
Centralna (wspólna) kartoteka wzorcowa tworzona jest przez zespół międzybiblioteczny. Przechowywana jest w pamięci komputera Biblioteki Uniwersytetu Warszawskiego. Zawiera cały zasób leksykalny KABA. W dniu 4.08.1995 Centralna Kartoteka Haseł Wzorcowych liczyła 41.764 rekordów, w tym 2.992 dla haseł przedmiotowych.

W każdej bibliotece współpracującej, w części modułu przeznaczonego na kartotekę wzorcową, zostanie powtórzona część KABA, składająca się z wyrażeń użytych w danej bibliotece do opracowania dokumentów.

Warunkiem wprowadzenia terminu do khw danej biblioteki jest jego poprzednia walidacja i wprowadzenie terminu do KABA.

Opracowanie przedmiotowe dokumentów będzie następowało w kolejnych etapach:

1. propozycja haseł przedmiotowych, prostych i rozwiniętych, dla opracowywanego dokumentu propozycja haseł do khw dla terminów wprowadzanych

2. korekta merytoryczna opisu przedmiotowego

3. korekta merytoryczna haseł do khw - poprawki według ustaleń wewnętrznych biblioteki

4. walidacja proponowanych haseł - poprawki według ustaleń zespołu międzybibliotecznego

5. wprowadzenie hasel, które uzyskały walidację do KABA i khw poszczególnych bibliotek ${ }^{5}$.

Zespół walidacyjny składa się z przedstawicieli zespołu koordynacyjnego KABA i bibliotekarzy odpowiedzialnych w poszczególnych bibliotekach za kartoteki języka haseł przedmiotowych. Komórką prowadzącą centralną bazę leksykalną khwjhp KABA jest Sekcja Srodków Lingwistycznych przy Oddziale Automatyzacji Biblioteki Uniwersytetu Warszawskiego. Jej pracownicy czuwają nad metodyką pracy zespołu, poprawnością formalną i merytoryczną walidowanych haseł oraz prowadzą szkolenia.

Obecnie w Polsce do zespołu bibliotek użytkujących program VTLS należą: Bibliteka Uniwersytetu Warszawskiego, Biblioteka Jagiellońska, Biblioteka Uniwersytetu Gdańskiego, Biblioteka Uniwersytetu Wrocławskiego. W 1994 r. do grupy tej przyłączyły się biblioteki lubelskie: Biblioteka Uniwersytetu Marii Curie-Skłodowskiej, Biblioteka Akademii Rolniczej, Biblioteka Politechniki Lubelskiej, Biblioteka Uniwersytecka Katolickiego Uniwersytetu Lubelskiego.

Pracownicy katalogu rzeczowego BU KUL biorą udział w szkoleniach, odbywają staże w BUW. Pozytywne zaliczenie staży, wykazanie się umiejętnością samodzielnej redakcji hasła do khw, jest warunkiem dopuszczenia do prac

${ }^{5}$ T. Głowacka, Nowy model organizacji opracowania przedniotowego dokumentów, „Przegląd Biblioteczny”, 62 (1994) z. 3/4, s. 219-224. 
zespołu walidacyjnego. Prócz tego Dyrekcja BU KUL podjęła starania o zapewnienie niezbędnego warsztatu pracy - zakup słowników języków RAMEAU i LCSH, indeksu Lavala (RVM) i czytnika.

Zespół pracowników katalogu rzeczowego Biblioteki musi opanować nową metodę pracy. Jest to zadanie niełatwe, zwłaszcza że ciągle równocześnie klasyfikujemy książki do katalogu systematycznego według dotychczasowych zasad. Nie zwiększyła się ilość etatów.

Planuje się, po okresie wdrożeniowym, pewnym nasyceniu terminami khw, zamknięcie katalogu systematycznego. Dokumenty będą opracowywane tylko zgodnie $\mathrm{z}$ jhp KABA. Język ten, przez umieszczenie, w terminach odrzuconych, odpowiedników francuskich i angielskich hasła, zapewnia możliwość wyszukiwania przy pomocy terminów w trzech językach naturalnych. Mamy nadzieję, że ułatwi to poszukiwania czytelników i pracę bibliotekarzy naszej Biblioteki, której większość zbiorów jest obcojęzyczna. Użycie jhp-KABA, który jest spójny gramatycznie z RAMEAU i LCSH, wzajemne powiązanie terminów tych języków, usprawni międzynarodową wymianę informacji. 